\title{
INFLUENCE OF ACICULAS DEPOSITION ON NATURAL REGENERATION IN SUB-WOODS OF Pinus taeda L. FOREST STAND
}

\author{
Guilherme Diego Fockink ${ }^{1 *}$, Tatiani Maria Pech ${ }^{1}$, Mayrine Silva ${ }^{2}$, Alexandre Siminski ${ }^{2}$, Júlia Carina Niemeyer ${ }^{2}$ \\ ${ }^{1}$ Universidade do Estado de Santa Catarina, Departamento de Engenharia Florestal, Programa de Pós-Graduação em Engenharia Florestal, \\ Lages, Santa Catarina, Brasil - guilhermefockink@gmail.com*, tatianimariapech@gmail.com
}

${ }^{2}$ Universidade Federal de Santa Catarina, Departamento de Agricultura, Biodiversidade e Florestas, Programa de Pós-Graduação em Ecossistemas Agrícolas e Naturais, Curitibanos, Santa Catarina, Brasil - mayrine.floresta@gmail.com, alexandre.siminski@ufsc.br, julia.carina@ufsc.br

Received for publication: 21/08/2018 - Accepted for publication: 01/07/2019

\begin{abstract}
Resumo
Influência da deposição de acículas sobre a regeneração natural em sub-bosque de povoamento de Pinus taeda $L$. O presente trabalho foi realizado em povoamento comercial de Pinus taeda L. localizado em Curitibanos, no Estado de Santa Catarina, Brasil. O objetivo deste trabalho foi avaliar a influência da barreira física ocasionada pela deposição de acículas, sobre os mecanismos de regeneração natural das espécies nativas em sub-bosque de povoamento de $P$. taeda L. Foram instaladas 3 parcelas $(10 \times 10 \mathrm{~m})$ no sub-bosque do povoamento, sendo avaliados a regeneração natural em subparcelas controle (presença de acículas) e limpas (ausência de acículas), a chuva de sementes e o banco de sementes do solo. Foram calculados os parâmetros de densidade e frequência (absolutas e relativas) e o índice de Shannon-Weaver (H'), sendo os valores de densidade total da chuva de sementes e banco de sementes submetidos a ANOVA $(p<0,05)$, e a densidade de plântulas regenerantes ao Teste $t$ de Student $(\mathrm{p}<0,05)$, através do Software R Studio ${ }^{\circledR}$. A densidade de plântulas regenerantes $\left(\right.$ ind. $\mathrm{m}^{-2}$ ) foi superior nas subparcelas limpas, estatisticamente. Não observou-se diferença estatística significativa para o parâmetro densidade (ind. $\mathrm{m}^{-2}$ ) entre as parcelas, para o banco de sementes do solo, somente para a chuva de sementes. O Índice de Diversidade de Shannon foi superior nas parcelas mais próximos ao fragmento em todos os mecanismos avaliados. Os resultados obtidos indicam que a camada de serapilheira age como barreira física ao recrutamento do banco de sementes e inviabiliza a chegada dos propágulos da chuva de sementes diretamente ao solo, dificultando o estabelecimento de plantas nativas e consequentemente a regeneração natural no sub-bosque.

Palavras-chave: Bioinvasão; Ecologia Florestal; Barreira física, Sucessão Ecológica.
\end{abstract}

\begin{abstract}
This study was conducted in a commercial forest stand of Pinus taeda L. located in Curitibanos, in the State of Santa Catarina, Brazil. The objective of this study was to evaluate the influence of the physical barrier caused by the deposition of aciculas, on natural regeneration mechanisms of native species in sub-woods of $P$. taeda L. forest stand. Three plots $(10 \times 10 \mathrm{~m})$ were installed in the sub-woods of the forest stand, and the natural regeneration was evaluated in the control (presence of aciculas) and clean (absence of aciculas) subplots, in addition to the seeds rain and soil seeds bank. The density and frequency parameters (absolute and relative) and the Shannon-Weaver Index ( $\left.\mathrm{H}^{\prime}\right)$ were calculated, and the total density values of the seeds rain and seeds bank were subjected to ANOVA $(\mathrm{p}<0.05)$, while the density of regenerative seedlings was subjected to Student's t Test $(\mathrm{p}<0.05)$, using the Software R Studio ${ }^{\circledR}$. The density of regenerative seedlings (ind. $\mathrm{m}^{-2}$ ) was higher in clean subplots, statistically. No significant statistical difference was observed for the density parameter (ind. $\mathrm{m}^{-2}$ ) among the subplots for the soil seeds bank, but only for the seeds rain. Shannon Diversity Index was higher in the plots closer to the fragment in all evaluated mechanisms. The obtained results indicate that the litter layer acts as a physical barrier to the breeding of the seeds bank and prevents the arrival of the seeds rain propagules directly to the soil, hindering the establishment of native plants and, consequently, the natural regeneration in the sub-woods.

Keywords: Bioinvasion; Forest Ecology; Physical barrier; Ecological Succession.
\end{abstract}

\section{INTRODUCTION}

Brazil has an area of 7.84 million hectares of planted forests, from which 1.6 million are cultivated with species of Pinus genus (IBÁ, 2017 - BRAZILIAN TREE INDUSTRY). The species of this genus play an essential role in the economy and development of the Southern region of Brazil, consisting of the main raw material for the movement of the forest industry in the region (VASQUES et al., 2007).

FLORESTA, Curitiba, PR, v. 50, n. 1, p. 1071 - 1080, jan/mar 2020.

Fockink, G. D. et.al.

ISSN eletrônico 1982-4688 
Pinus species were initially introduced in Brazil for ornamental purposes by European immigrants. The first experiences related to Pinus forestry in Brazil occurred in 1948, initiated by the Forest Service of the State of São Paulo, with the introduction of American pines species. In Southern Brazil, Pinus taeda L. and Pinus elliottii Engelm. species showed a good adaptability, because they are resistant to frequent frosts (SHIMIZU, 2008). These species were introduced in this region through tax incentives that aimed to develop the country in the decades of 1960 and 1970 (VASQUES et al., 2007). Due to the intense exploitation condition of the Atlantic Forest and the scarcity of natural resources already in this period, Pinus has become a feasible alternative to supply the wood demand, therefore enabling the native forest conservation (SERVIÇO FLORESTAL BRASILEIRO, 2018).

Despite the economic relevance of Pinus genus, it shows a biological invader potential due to its characteristics of wind dispersion, competition for the regeneration niche with native species, and success in colonizing inhospitable environments to the other species, such as poor and dry soils (RICHARDSON; BOND, 1991). In addition to the invader potential, the forest stands of Pinus sp. prevent the installation of other plant species in its sub-woods, and according to Voltolini \& Zanco (2010) it occurs by the negative effect caused by the deposition of thick litter layers in the sub-woods, preventing the seeds germination. Senbeta et al. (2002) also point out that the sub-woods shading is another condition that hinders the regenerative development in subwoods.

The natural regeneration evaluation under exotic forest plantations is of great relevance to understand the ecology of these ecosystems and how the natural regeneration processes occur in systems under its influence. The existing literature on the subject needs to be complemented, since most studies are only targeted to the identification of native species present in sub-woods of pinus stands, not evaluating regeneration factors and feasibility in these environments (VIANI et al., 2010).

In this context, this study aimed to evaluate the influence of the physical barrier caused by the deposition of aciculas on natural regeneration mechanisms of native species in the sub-woods of $P$. taeda $\mathrm{L}$ forest stand.

\section{MATERIAL AND METHODS}

\section{Characterization of the study area}

The experiment was conducted in 2017 in a commercial forest stand of $P$. taeda (12 years), located at Fazenda Pessegueirinho in the city of Curitibanos, Santa Catarina, Brazil. Curitibanos is located in the central plateau of Santa Catarina, with South latitude $27^{\circ} 16^{\prime} 58^{\prime \prime}$ and West latitude $50^{\circ} 35^{\prime} 04^{\prime \prime}$, at an altitude of 987 meters. The climate, according to Köppen-Geiger classification, is temperate (cfb), humid mesothermic and with mild summer, with the average temperature in the coolest month below $18^{\circ} \mathrm{C}$ and the average temperature of the warmest month exceeds $22^{\circ} \mathrm{C}$. The study area is in the Atlantic Forest Biome, with phytophysiognomy of Mixed Ombrophilous Forest (FOM), geological formation of General Mountain, and the predominant soil is Humic Tb A Haplic Cambisol with very clayed texture, occurring in wavy relief (IBGE, 2012; POTTER et al., 2004).

The forest stand was implemented in 2005, in a spacing of $2.5 \times 2.5 \mathrm{~m}$, and has been managed for the production of wood for lamination, sawmill and processes. The area suffered 2 systematic thinning (2014 and 2017), and the first rotation cycle with Pinus, while the previous soil use consisted of pasture with some isolated tree species.

\section{Sampling and sample design}

For implementing the experiment a fully randomized design was used. The sampling inside the pinus forest stand was performed by the fixed plots method in the field. Three plots $(10 \mathrm{~m} \times 10 \mathrm{~m})$ were installed perpendicularly to the fragment of adjacent native vegetation, keeping $20 \mathrm{~m}$ distant from the pinus stand border and $10 \mathrm{~m}$ distant among the plots. In each plot the seeds rain and soil samples were collected to evaluate the seeds bank. The natural regeneration was evaluated by the installation of subplots $(1.0 \mathrm{~m} \mathrm{x} 1.0 \mathrm{~m})$ with the presence and absence of aciculas (Figure 1). 


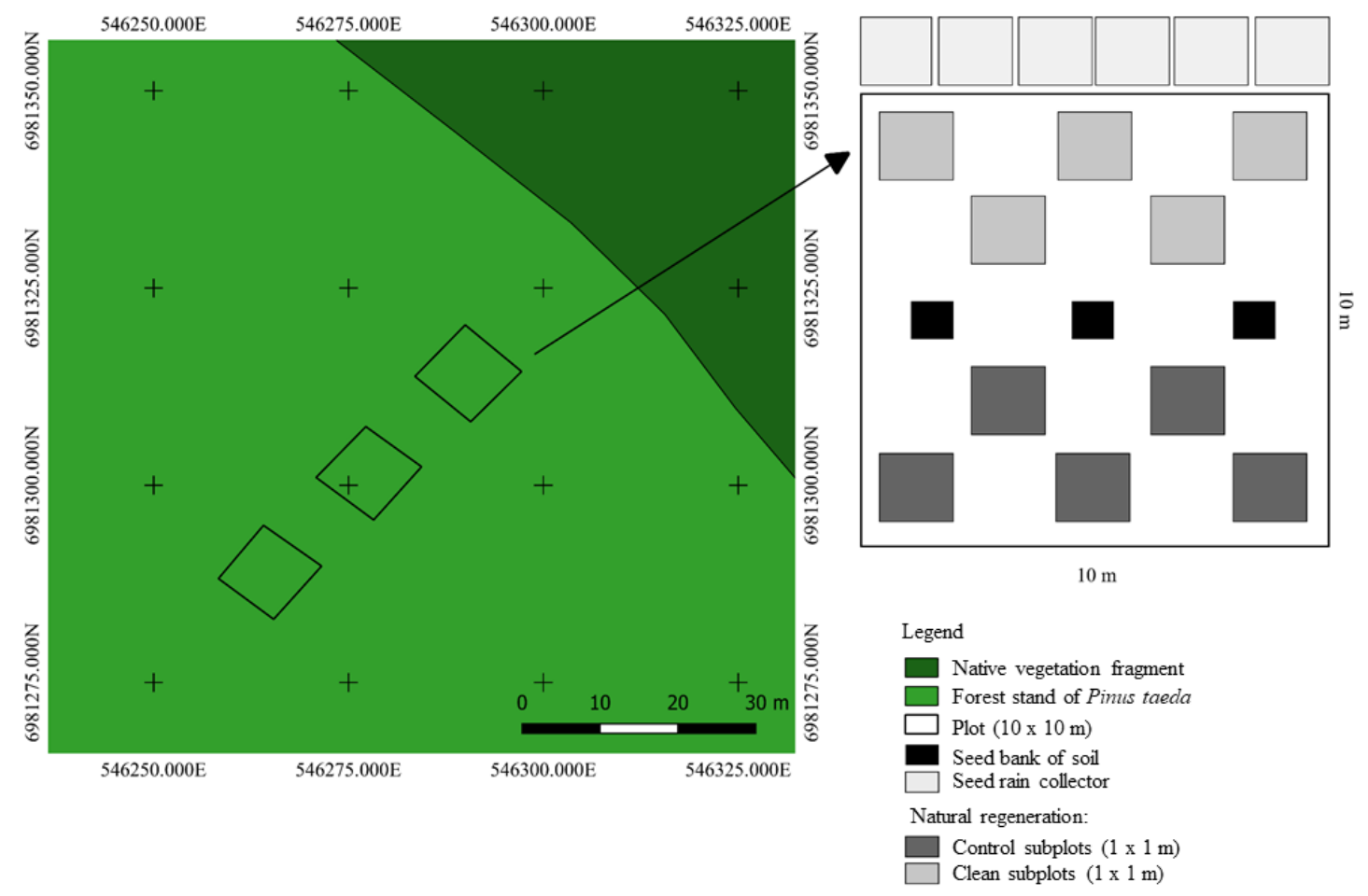

Figure 1. Sample design of the evaluations carried out inside the forest stand of $P$. taeda. Source: Author (2018).

Figura 1. Desenho amostral das avaliações realizadas no interior do povoamento de $P$. taeda. Fonte: Autor (2018).

\section{Evaluation of the soil seeds bank}

To evaluate the soil seeds bank, 3 soil samples were collected per plot, totaling 9 samples. Quadrants were demarcated in the central line of each plot (Figure 1) in the dimensions of $30 \mathrm{~cm} \times 30 \mathrm{~cm}$ and $5 \mathrm{~cm}$ deep, using rulers, and the soil cut was performed with a shovel. Before the sampling, the aciculas layer existing on the demarcated area was removed and discarded for the soil sampling. Subsequently the soil samples were arranged in trays containing a $5 \mathrm{~cm}$ thick layer of sand (washed and dry), and 20 perforations in the bottom to allow the water draining. They were allocated in a greenhouse, according to the methodology adapted from Cadalto et al. (1996) and Gonçalves et al. (2008). The seedlings that germinated were quantified weekly until the $6^{\text {th }}$ week, and fortnightly until the $14^{\text {th }}$ week, according to the methodology proposed by Gonçalves et al. (2008). Subsequently, they were classified into morphotypes, and the botanical identification was performed according to the literature, as soon as they reached a size that allowed identification. Seedlings were also classified according to the life form as arboreal, herbaceous and shrubby.

\section{Evaluation of seeds rain}

To evaluate the seeds rain, 6 wood collectors $(50 \mathrm{~cm} \times 50 \mathrm{~cm})$, with nylon net $(2 \mathrm{~mm}$ mesh) at the bottom, at a height of $20 \mathrm{~cm}$ from the soil were systematically distributed in the anterior line of each plot (Figure). The seeds rain was collected monthly for a period of 1 year (Jan/2017 - Dec/2017), according to the methodology proposed by Cadalto et al. (1996). In the laboratory, the collected material was subjected to drying in an air circulation greenhouse $\left(\mathrm{T}=55^{\circ} \mathrm{C}\right)$, and subsequently separated from the inert material (twigs, aciculas and reproductive cones). Previously screened seeds and fruits were identified at family, genus and species levels, when possible. Diaspores were also classified according to the dispersion syndrome and ecological group, according to the literature.

\section{Evaluation of natural regeneration}

In order to evaluate the natural regeneration within the pinus forest stand, 10 subplots $(1.0 \times 1.0 \mathrm{~m})$ were allocated in each plot, systematically distributed (Figure 1), and in 5 subplots the cleaning was performed (removal of aciculas layer) monthly, for a period of 1 year, and in the other 5 subplots the aciculas layer was

FLORESTA, Curitiba, PR, v. 50, n. 1, p. 1071 - 1080, jan/mar 2020.

Fockink, G. D. et.al.

ISSN eletrônico 1982-4688

DOI: $10.5380 /$ rf.v50 i1.61136 
maintained (control). In the control subplots, for the evaluation effectiveness, all seedlings existing at the time of their implantation were removed. After 1 year period (Dec/2016 - Dec/2017) the regenerative seedlings were surveyed, and the height inclusion class was higher than $5 \mathrm{~cm}$. Regenerative seedlings were collected and taken to the Ecology and Plant Morphophysiology laboratory of the Federal University of Santa Catarina - Campus Curitibanos for further identification at the family, genus and species level, when possible. The identification was performed using the literature and experts of the area.

\section{Data analysis}

The checking of the sample sufficiency of the sapling method used to evaluate the natural regeneration was carried out through a species accumulation curve. This was performed using the software Estimates 9.1.0 ${ }^{\circledR}$. Total density (ind. $\mathrm{m}^{-2}$ ), density and frequency parameters were applied in their absolute and relative forms for each species, and the Shannon-Weaver Diversity Index (H') was used for the natural regeneration, seeds bank and seeds rain characterization, according to the equations proposed by Felfili \& Rezende (2003). The data analysis of regenerative plants density in the clean and control subplots was performed using the Student's $t$ Test, unilateral and unicaudal. Seeds bank density and seeds rain density data among the sampled plots were subjected to ANOVA, followed by Tukey Test $(\mathrm{p}<0.05)$, using the TukeyHSD () command. All statistical analyses were performed using the Software R Studio ${ }^{\circledR}$.

\section{RESULTS}

During the 14-weeks period in the greenhouse, the emergence of a total of 2,762 seeds was observed, totaling 3409.9 sampled seeds. $\mathrm{m}^{-2}$. The seeds average density (seeds. $\mathrm{m}^{-2}$ ) showed no statistically significant difference among the plots, when subjected to ANOVA $(\mathrm{p}<0.05)($ Table 1$)$.

The floristic composition of the soil seeds bank showed 46 species, divided into 14 families, and 9 of them were identified only at family level and 6 at genus level. Other 24 non-identified seedlings were classified as morphotypes. The major relative densities were observed for the herbaceous species Digitaria sp. 1, Cyperaceae (morphotype 1), Amaranthus sp. and non-identified (morphotype 24). And also the major relative frequencies, for Sonchus sp., Cyperaceae (morphotype 1), Digitaria sp. 1 and non-identified (morphotype 24). Regarding the diversity of species found in the soil seeds bank, by means of the Shannon - Weaver Index (H'), higher values were observed for plot $1\left(\mathrm{H}^{\prime}=2.50\right)$ and plot $2\left(\mathrm{H}^{\prime}=2.39\right)$. For plot 3 the diversity found was lower $\left(\mathrm{H}^{\prime}=1.91\right)$ (Table 4).

Among the observed species, $43.5 \%$ were classified as herbaceous and $4.3 \%$ as arboreal. The nonidentified individuals were classified in morphotypes and correspond to $52.2 \%$ of the germinated seedlings. The arboreal species were little representative in the seeds bank composition, and were represented by Mimosa scabrella Benth. and Zanthoxylum rhoifolium Lam., with 4 and 2 germinated individuals, respectively.

Table 1. Mean seed bank density, seed rain and dispersion syndrome (\%) within the forest stand of pinus.

Tabela 1. Densidade média do banco de sementes, chuva de sementes e síndrome de dispersão (\%) no interior do povoamento de pinus.

\begin{tabular}{cccccc}
\hline & \multicolumn{2}{c}{ Mean density $\left(\right.$ seed.m- $\left.{ }^{2}\right)$} & \multicolumn{2}{c}{ Dispersion syndrome (\%) } \\
\hline Plot & Seed bank & \multicolumn{2}{c}{ Seed rain } & Zoocoric & Anemocoric \\
\hline 1 & - & Nativas & Pinus & - & - \\
2 & $288,89 \mathrm{a}$ & $66,7 \mathrm{a}$ & $60,7 \mathrm{a}$ & $50 \%$ & $50 \%$ \\
3 & $450,21 \mathrm{a}$ & $47,3 \mathrm{ab}$ & $58,7 \mathrm{a}$ & $50 \%$ & $50 \%$ \\
\hline
\end{tabular}

Source: Author (2018); * Means followed by the same lowercase letter in the column did not present significant statistical difference by the Tukey test $(\mathrm{p}<0.05)$.

Fonte: Autor (2018); *Médias seguidas da mesma letra minúscula na coluna não apresentam diferença estatística significativa pelo Teste de Tukey $(\mathrm{p}<0,05)$.

In the floristic composition of the seeds rain, a total of 18 species was found (fruits and seeds), distributed in 8 botanical families, and 5 species were not identified. Asteraceae and Poaceae families had the highest number of species in the sampled units. The seeds with the highest relative density correspond to $P$. taeda (61.2\%), Asteraceae (Morphotype 1 (19.4\%), Araucaria angustifolia (Bertol.) Kuntze (6.3\%) and Myrsine coriacea (Sw.) R. Br. (4.9\%). The seeds with the highest relative frequency correspond to P. taeda, Asteraceae (Morphotype 1) and Poaceae (Morphotype 1), both with $9.7 \%$. The high relative density and frequency shown by the seeds of $P$. taeda indicate that the species has homogeneous dispersion throughout the forest stand. And the 
high relative density observed for the seeds of A. angustifolia can be justified by the occurrence of some individuals of the species in isolated form amidst the pinus forest stand.

The seeds rain density of native species showed significant statistical difference among the plots, while the seeds rain density of $P$. taeda showed no significant difference when subjected to ANOVA followed by Tukey Test $(\mathrm{p}<0.05)$. The average values of the seeds rain density of native species and pinus can be observed in Table 1.

Shannon-Weaver Diversity Index (H') resulted in a greater diversity of species for the plots closer to the native vegetation fragment, with $H^{\prime}=1.16$ for plot 1 (distance of $20 \mathrm{~m}$ ), $\mathrm{H}^{\prime}=1.51$ for plot 2 (distance of 40 $\mathrm{m}$ ) and $\mathrm{H}^{\prime}=0.59$ for plot 3 (distance of $60 \mathrm{~m}$ ) (Table 4). Regarding the dispersal syndromes, it is observed that, when getting into the forest stand of $P$. taeda, from the distance of $40 \mathrm{~m}$ (Plot 2), the percentage of species with zoocoric syndrome decreased, while the percentage of species with anemocoric syndrome increased (Table 1).

Figure 2 shows the species accumulation curve. For the purpose of reporting the regenerative species richness in the planting of $P$. taeda, the sampling should be expanded, however, it is considered that the sampling was sufficient to indicate the accumulation effect of aciculas on the regeneration, and so meet the proposed objective.

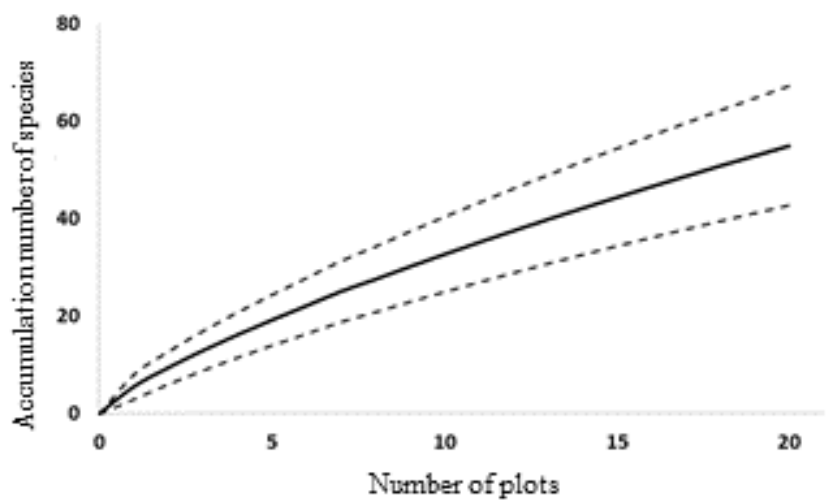

Figura 2. Curva de acumulação de espécies com os limites de confiança indicados pelas linhas pontilhadas. Fonte: Autor (2018).

Figure 2. Species accumulation curve with the confidence limits indicated by dotted lines. Source: Author (2018).

The average density of regeneratives was 132 individuals. $\mathrm{m}^{-2}$ in clean subplots, while for the control subplots (with aciculas) the average density was 48.2 individuals. $\mathrm{m}^{-2}$, and the differences between the values was statistically significant $(\mathrm{p}<0.05$; Student's t Test). Eighteen regenerative arboreal individuals were observed in the clean subplots (Table 2), while in the control subplots, only 2 arboreal individuals were found (Table 3). The density of arboreal individuals also showed a significant statistical difference $(\mathrm{p}<0.05$; Student's $t$ Test $)$, evidencing a higher density of arboreal individuals in clean subplots. In Table 2 the relative density and frequency can also be verified for each regenerative species found in clean subplots, in addition to the life form that they are classified.

Table 2. Relative density and frequency and classification as the life form for the regenerating species found in the clean subplots (without aciculas).

Tabela 2. Densidade e frequência relativas e classificação quanto a forma de vida para as espécies regenerantes encontradas nas subparcelas limpas (sem acículas).

\begin{tabular}{|c|c|c|c|c|c|}
\hline Family & Species & FV & $\mathbf{N}$ & DR & FR \\
\hline Amarhantaceae & Amaranthus sp. & Herbaceous & 5 & 0,38 & 2,63 \\
\hline Asteraceae & Baccharis sp. & Subshrubs & 5 & 0,38 & 1,32 \\
\hline Asteraceae & Conyza sp. & Herbaceous & 9 & 0,68 & 5,26 \\
\hline Asteraceae & Galinsoga sp. & Herbaceous & 1 & 0,08 & 1,32 \\
\hline Asteraceae & Sonchus sp. & Herbaceous & 9 & 0,68 & 3,95 \\
\hline Bignoniaceae & Dolichandra sp. & Liana & 9 & 0,68 & 2,63 \\
\hline Brassicaceae & Cardamine bonariensis Pers. & Herbaceous & 1 & 0,08 & 1,32 \\
\hline Commelinaceae & Commelina benghalensis L. & Herbaceous & 4 & 0,30 & 1,32 \\
\hline
\end{tabular}

FLORESTA, Curitiba, PR, v. 50, n. 1, p. 1071 - 1080, jan/mar 2020.

Fockink, G. D. et.al.

ISSN eletrônico 1982-4688 


\begin{tabular}{|c|c|c|c|c|c|}
\hline Convolvulaceae & Morfotipo 1 & Herbaceous & 19 & 1,44 & 6,58 \\
\hline Convolvulaceae & Morfotipo 2 & Herbaceous & 1 & 0,08 & 1,32 \\
\hline Cyperaceae & Cyperus sp. & Herbaceous & 139 & 10,53 & 11,84 \\
\hline Euphorbiaceae & Morfotipo 1 & Arboreal & 1 & 0,08 & 1,32 \\
\hline Fabaceae & Desmodium sp. & Herbaceous & 14 & 1,06 & 5,26 \\
\hline Malvaceae & Morfotipo 1 & Herbaceous & 2 & 0,15 & 1,32 \\
\hline Malvaceae & Sida $\mathrm{sp}$ & Subshrubs & 1 & 0,15 & 2,63 \\
\hline Oxalidaceae & Oxalis corniculata $\mathrm{L}$. & Herbaceous & 1 & 0,08 & 1,32 \\
\hline Pinaceae & Pinus taeda $\mathrm{L}$. & Arboreal & 3 & 0,23 & 2,63 \\
\hline Plantaginaceae & Plantago tomentosa Lam. & Herbaceous & 2 & 0,15 & 2,63 \\
\hline Poaceae & Digitaria sp. 1 & Herbaceous & 1045 & 79,17 & 13,16 \\
\hline Poaceae & Digitaria sp 2 & Herbaceous & 3 & 0,23 & 2,63 \\
\hline Poaceae & Eragrostis plana Ness. & Herbaceous & 11 & 0,83 & 2,63 \\
\hline Poaceae & Lolium sp. & Herbaceous & 1 & 0,08 & 1,32 \\
\hline Poaceae & Paspalum sp. & Herbaceous & 2 & 0,15 & 1,32 \\
\hline Primulaceae & $\begin{array}{l}\text { Myrsine coriacea (Sw.) R. Br. Ex. Roem. \& } \\
\text { Schult. }\end{array}$ & Arboreal & 3 & 0,23 & 1,32 \\
\hline Rutaceae & Zanthoxylum rhoifolium Lam. & Arboreal & 11 & 0,83 & 6,58 \\
\hline Solanaceae & Morphotype 1 & - & 1 & 0,08 & 1,32 \\
\hline Solanaceae & Morphotype 2 & - & 1 & 0,08 & 1,32 \\
\hline Solanaceae & Morphotype 3 & - & 2 & 0,15 & 1,32 \\
\hline Solanaceae & Morphotype 4 & - & 2 & 0,15 & 1,32 \\
\hline Solanaceae & Solanum americanum Mill. & Herbaceous & 2 & 0,15 & 1,32 \\
\hline Thelypteridaceae & Thelypteris dentata (Forssk.) E. P. St. John & Herbaceous & 2 & 0,15 & 2,63 \\
\hline Not identified & Morphotype 1 & - & 1 & 0,08 & 1,32 \\
\hline Not identified & Morphotype 2 & - & 2 & 0,15 & 1,32 \\
\hline Not identified & Morphotype 3 & - & 3 & 0,23 & 1,32 \\
\hline Not identified & Morphotype 4 & - & 1 & 0,08 & 1,32 \\
\hline Grand total & - & - & 1319 & 100 & 100 \\
\hline
\end{tabular}

In clean subplots, 35 regenerative species were found, divided into 18 botanical families. From these $57.2 \%$ were classified as herbaceous, $11.4 \%$ as arboreal, $5.7 \%$ as subshrubs, $2.9 \%$ as lianas, and $22.9 \%$ were not classified regarding the life form. Standing out with higher relative density and frequency among the regenerative are the herbaceous species Digitaria sp.1 and Cyperus sp. (10.53\%) as observed in Table 2. Considering only the regenerative arboreal individuals in clean subplots, the highest relative densities and frequencies were presented by $Z$. rhoifolium and $P$. taeda

Regenerative species found in control subplots (with aciculas) can be observed in Table 3, and also their relative densities and frequencies, and life forms. In control subplots, 15 species were found, divided into 9 botanical families. From these $60.0 \%$ were classified as herbaceous, $13.3 \%$ as arboreal, $6.7 \%$ as shrubby, $6.7 \%$ as lianas, and $13.3 \%$ were not classified regarding the life form. The major relative densities and frequencies were presented by the herbaceous species Digitaria sp. 1 and Desmodium sp. (Table 3). Regarding the arboreal species, these showed low relative densities and frequencies in control subplots, as shown in Table 3 . The presence of invasive exotic gramineous is also observed, as in the case of E. plana in both treatments and Brachiaria sp. only in control subplots. However, they pose no risk to the area due to the low densities and frequencies that they occur (Table 2 and 3).

Table 3. Relative density and frequency and classification as the life form for the regenerating species found in the control subplots (with aciculas).

Tabela 3. Densidade e frequência relativas e classificação quanto a forma de vida para as espécies regenerantes encontradas nas subparcelas controle (com acículas).

\begin{tabular}{llcccc}
\hline Family & Species & FV & N & DR & FR \\
\hline Asteraceae & Conyza sp. & Herbaceous & 1 & 0,21 & 3,13 \\
Asteraceae & Galinsoga sp & Herbaceous & 2 & 0,41 & 3,13 \\
Bignoniaceae & Dolichandra sp. & Liana & 3 & 0,62 & 6,25 \\
\hline
\end{tabular}




\begin{tabular}{llcccc}
\hline Brassicaceae & Cardamine bonariensis Pers. & Herbaceous & 4 & 0,83 & 6,25 \\
Convolvulaceae & Morfotipo 1 & Herbaceous & 2 & 0,41 & 6,25 \\
Cyperaceae & Cyperus sp. & Herbaceous & 2 & 0,41 & 3,13 \\
Fabaceae & Desmodium sp. & Herbaceous & 18 & 3,73 & 18,75 \\
Lauraceae & Nectandra sp. & Arboreal & 1 & 0,21 & 3,13 \\
Melastomataceae & Morfotipo 1 & Shrubby & 1 & 0,21 & 3,13 \\
Poaceae & Brachiaria sp. & Herbaceous & 1 & 0,21 & 3,13 \\
Poaceae & Digitaria sp. 1 & Herbaceous & 443 & 91,91 & 31,25 \\
Poaceae & Eragrostis plana Ness. & Herbaceous & 1 & 0,21 & 3,13 \\
Not identified & Morphotype 5 & Arboreal & 1 & 0,21 & 3,13 \\
Not identified & Morphotype 6 & - & 1 & 0,21 & 3,13 \\
Not identified & Morphotype 7 & - & 1 & 0,21 & 3,13 \\
\hline Grand total & - & - & 482 & 100 & 100 \\
\hline
\end{tabular}

Source: Author (2018); Legend: FV = Life form; DR = Relative Density (\%); FR = Relative Frequency (\%).

Fonte: Autor (2018); Legenda: FV = Forma de vida; N = Número de indivíduos; DR = Densidade Relativa $(\%)$; FR = Frequência Relativa $(\%)$.

From the species observed in both treatments, 26 occurred exclusively in clean subplots, while just 6 occurred only in control subplots. The Shannon-Weaver Diversity Index (H') resulted in a greater diversity of species for the clean subplots $\left(H^{\prime}=0.97\right)$, and lower diversity for the control subplots $\left(H^{\prime}=0.44\right)$. In Table 4 the Shannon-Weaver diversity values $\left(\mathrm{H}^{\prime}\right)$ can be observed for the soil seeds bank, seeds rain and natural regeneration (clean and control plots).

Table 4. Shannon-Weaver diversity $\left(\mathrm{H}^{\prime}\right)$ values for each regeneration mechanism evaluated.

Tabela 4. Valores de diversidade de Shannon-Weaver (H') para cada mecanismo de regeneração avaliado.

\begin{tabular}{ll|ll|ll}
\hline Seed bank of soil & H' & Seed rain & H' & Natural regeneration & H' \\
\hline Plot 1 & 2,50 & Plot 1 & 1,16 & Clean subplots & 0,97 \\
Plot 2 & 2,39 & Plot 2 & 1,51 & Control subplots & 0,44 \\
Plot 3 & 1,91 & Plot 3 & 0,59 & & \\
\hline
\end{tabular}

Source: Author (2018); Legend: H' = Diversity of Shannon-Weaver.

Fonte: Autor (2018); Legenda: H' = Diversidade de Shannon-Weaver.

\section{DISCUSSION}

Gonçalves et al. (2008) observed a seedling emergence density in a greenhouse of 3626.67 seeds.m-2 $^{2}$ when evaluating the seeds bank of a forest stand of $P$. caribaea var. hondurensis, corroborating the results observed in this study. Regarding the floristic composition of the soil seeds bank, Schorn et al. (2013) verified a richness of 25 species when evaluating the seeds bank of an area with reforestation of Pinus sp. in the Atlantic Forest biome. These authors also found in their study the predominance of herbaceous species, followed by shrubs and trees, demonstrating the initial stage of subwoods regeneration, which corroborates the data verified in this study. The predominance of herbaceous in the seeds bank verified in this study can be justified due to the higher number of herbaceous species seeds, compared to the arboreal species, in the soil seeds bank, resulting from the forest management interventions held in the stands canopy (GONÇALVES et al., 2008). Concerning the occurrence of arboreal species in the soil seeds bank of forest stands of Pinus sp., some authors verified its occurrence as little expressive $\left(<10\right.$ individuals. $\left.\mathrm{m}^{2}\right)$ or also the non-occurrence of this form of life (BECHARA et al., 2014; SCHORN et al., 2013; SENBETA et al., 2002). According to Schorn et al. (2013), the canopy of forest stands of Pinus sp. hinder the dispersion and incorporation of local flora seeds in the soil seeds bank, reflecting in the low density of arboreal species found in the subwood.

Observing the floristic composition of the seeds bank, this can be characterized as a persistent seeds bank due to the predominance of pioneer species: herbaceous and arboreal (M. scabrella and Z. rhoifolium). A persistent seeds bank is composed of pioneer species that are intolerant to shadow, and which remain feasible in the soil for longer periods, being responsible for the vegetation regeneration in case of disturbances and in unfeasibility conditions of the seeds rain (CADALTO et al.,1996; MARTINS et al., 2012).

Comparing the floristic composition of the seeds rain and soil seeds bank, it is observed that few species are similar among the evaluated mechanisms, that is, the seeds rain contributes little to the soil seeds bank formation in the forest stand of $P$. taeda. The high number of herbaceous species found evidences a more expressive contribution of the vegetation that existed in the site before the implementation of the forest stand of P. taeda. Araujo et al. (2001) highlights that the predominance of a life form in the seeds bank depends on the type of pressions suffered in the area and its surroundings, and the herbaceous, gramineous and shrubs species

FLORESTA, Curitiba, PR, v. 50, n. 1, p. 1071 - 1080, jan/mar 2020.

Fockink, G. D. et.al.

ISSN eletrônico 1982-4688

1077

DOI: $10.5380 /$ rf.v50 i1.61136 
are common in the soil seeds bank composition in areas that have been used for agricultural crops and/or pastures.

The emergence of $P$. taeda seedling was not observed in the soil seeds bank, despite the presence of propagules of the species in the seeds rain homogeneously in all the sampled units, and this possibly indicates that the litter layer prevents the arrival of these seeds into the soil. This behavior was also observed by Bechara et al. (2014) when evaluating the oil seeds bank in the forest stand of P. elliottii.

In the natural regeneration evaluation, a higher density of regenerative seedlings was observed in clean subplots (with no aciculas, 132 ind. $\mathrm{m}^{-2}$ ) compared to the control subplots (with aciculas, 48.2 ind. $\mathrm{m}^{-2}$ ). This result corroborates the initial hypothesis that the deposition of aciculas hinders the natural regeneration of seedlings in the subwoods of pinus forest stands.

Herbaceous species showed high values of relative densities and frequencies in both treatments, with more than $50 \%$ of the life forms observed. According to Ferracin et al. (2010), the coverage of herbaceous in the subwoods of the forest stands of $P$. taeda is inversely proportional to the canopy coverage, and its development depends on the luminosity that reaches the subwood. The same author also points out that high percentages of herbaceous coverage can potentiate the physical barrier formed by aciculas, preventing the germination of native species and, consequently, the natural regeneration. The presence of Digitaria sp.1 gramineous species in higher density and frequency in control and clean subplots can be justified by the planting spacing. Modna et al. (2010) point out that forest stands of $P$. elliottii showed a higher amount of gramineous in larger spacing, tending to decrease in smaller spacing due to the shading action promoted by the canopy.

A total of 6 regenerative arboreal species (20 individuals) was observed in the subwood of pinus forest stand, with 4 species in the clean subplots and 2 in the control subplots (Table 2 and 3). Other authors have verified the presence of arboreal species in a quantity higher than that observed in this study, in evaluations performed in forest stands of Pinus sp. in different ages. Senbeta et al. (2002) when evaluating the regeneration in a forest stand of $P$. patula at 10 years of age in Ethiopia found 12 regenerative arboreal species. Carvalho et al. (2016) when evaluating the arboreal regeneration in a forest stand of Pinus sp. at 30 years of age verified the presence of 58 species, in the Atlantic Forest Biome (Mixed Ombrophilous Forest). The same author also highlights that the number of regenerative species is directly related to the intensity of the forest stand management and its connectivity with the adjacent native forest fragments. Richness results are also dependent on the sample effort and, as shown by the species accumulation curve, the sampling should be more extensive for determining the richness in the studied area.

Despite the absence of $P$. taeda seedling in the soil seeds bank, the regeneration of this species was observed only in the clean subplots (with no aciculas) (Table 2). In control subplots, seeds of this species were found germinated in the middle of the aciculas layer, with no establishment of seedlings. Venzke et al. (2012) when evaluating the regeneration in the subwood of Pinus caribaea forest stands in the presence of the aciculas layer verified the absence of seedling regeneration of $P$. taeda. The inexistence of $P$. taeda regeneration in the control subplots and in the soil seeds bank is an indicative that the litter layer formed by aciculas may have an insulating effect on the seeds rain, preventing the arrival of the diaspores directly to the soil and acting as a physical barrier to natural regeneration.

The regeneration of $Z$. rhoifolium in clean subplots (Table 2), and its presence in the soil seeds bank reiterates the hypothesis that the removal of the aciculas layer facilitates the natural regeneration, mainly of pioneer species, present in the seeds bank. The regeneration of $M$. coriacea may be associated with the zoocoric dispersion, since the species was not observed in the floristic composition of the soil seeds bank, but rather in the seeds rain. Its occurrence only in the clean subplots is possibly due to the easy access to the soil by the diaspores, which in the control subplots becomes unfeasible due to the thick layer of aciculas. The presence of species of Nectandra sp. genus in the subwood of Pinus sp. was observed by other authors when evaluating the regeneration of woody species in the presence of a layer of aciculas (CARVALHO et al., 2016; LOPES et al., 2016; VENZKE et al., 2012), corroborating the findings in this study.

The species diversity verified for the soil seeds bank and seeds rain through the Shannon-Weaver Index $\left(H^{\prime}\right)$ was higher for the plots closer to the adjacent native vegetation fragment. However, for the seeds rain the greater diversity was observed in plot 2 . The presence of individuals of A. angutifolia in this sampling unit was observed (in the middle of the pinus plantation) and may have contributed to this result, acting as an attractive for the dispersive wildlife and, consequently, increasing the number of plant species spread in this area. The greatest diversity of species observed in the plots closer to the adjacent native vegetation fragment may be related to the dispersal syndrome of the species. Bechara et al. (2014) points out that species with zoocoric dispersion tend to decrease inside the forest stand, which is according to the verified in this study.

The density of native species seeds rain was also higher in plots 1 and 2 (Table 1), possibly related to the greater zoocoric dispersion in this area. Keenan et al. (1997) emphasize that in order to have a homogeneous 
seed dispersion the seed dispersing agents should act uniformly in all parts of the forest stand. In the case of the forest stand evaluated in this study, the decrease in the zoocoric dispersion within the forest stand, the predominance of a matrix of forest stands in the landscape, and the reduced size of adjacent native vegetation fragments may be factors affecting the native seeds dispersion within the forest stand and, consequently, the regenerative native species diversity.

For the natural regeneration, the species diversity was higher in the clean subplots (with aciculas) compared to the control subplots (with no aciculas), showing that the removal of the aciculas layer increases the density and diversity of regeneratives. Diversity values observed by other authors for the natural regeneration in forest stands of Pinus sp. (CARVALHO et al., 2016; LOPES et al., 2016; SENBETA et al., 2002) are higher than those observed in this study, because they only consider the arboreal-shrubby regeneration and are mainly performed in forest stands in advanced ages and poorly managed.

Some authors mention species of Pinus genus as facilitators of the regeneration of native woody species (MODNA et al., 2010; OLIVEIRA et al., 2017) and point out that this characteristic is directly related to the spacing and luminosity conditions in forest stands, disregarding in their assessments possible effects caused by the presence of thick layers of aciculas. However, the results obtained in this study clearly demonstrate that the aciculas layer can directly interfere with the natural regeneration mechanisms in the subwood of forest stands, and which impediment of regeneration is due to the physical barrier action.

\section{CONCLUSIONS}

- The litter layer produced by the forest stands of $P$. taeda acts as a physical barrier on the natural regeneration of native species, hindering the breeding of regenerative seedlings that are present in the soil seeds bank, and hindering the access to the soil of diaspores that get into the plots through the seeds rain. Therefore, the removal of the litter layer allows the development of a higher density of plants and a greater diversity of species, when compared to sites with the presence of aciculas layer.

- It is noteworthy that in forest stands of commercial $P$. taeda, the development of regeneration in the subwood is unwanted, and the litter layer is important in this context because it acts in the control of weeds and other regenerative species. From the point of view of the restoration, in ecosystems that suffered invasion by $P$. taeda the removal of the litter layer can be interesting after the removal of the invasive exotic species, which will facilitate the natural regeneration process of the area.

- Complementary studies shall be carried out to evaluate the long-term regeneration behavior in the absence of the aciculas layer, in addition to evaluating the mechanisms that contribute to the regeneration in the subwood of pinus forest stands.

\section{ACKNOWLEDGEMENTS}

We are grateful to Gaboardi Agropastoril Ltda. for granting the study area and the support to our activities.

\section{REFERENCES}

ARAUJO, M. M.; OliVEIRA, F. A.; VIEIRA, I. C. G.; BARROS, P. L. C.; LIMA, C. A. T. Densidade e composição florística do banco de sementes do solo de florestas sucessionais na região do Baixo Rio Guamá, Amazônia Oriental. Scientia Forestalis, Piracicaba, n. 59, p. 115-130, 2001.

BECHARA, F. C.; REIS, A.; TRENTIN, B. E. Invasão biológica de Pinus elliottii var. elliottii no Parque Estadual do Rio Vermelho, Florianópolis, SC. Revista Floresta, Curitiba, v. 44, n. 1, p. 63 -72, 2014.

CADALTO, S. L.; FlOSS, P. A.; CROSE, D. M.; LONGHI, S. J. Estudo da regeneração natural, banco de sementes e chuva de sementes na reserva genética florestal de Caçador, SC. Ciência Florestal, Santa Maria, v.6, n.1, p. 27 - 38, 1996.

CARVALHO, J.; VELAZCO, S. J.; PEREIRA, T. K.; GALVÃO, F. Regeneração natural em povoamentos de Araucaria angustifolia e Pinus sp. em Tunas do Paraná, PR. Pesquisa Florestal Brasileira, Colombo, v. 36, n. 85, p. 9 - 16, 2016.

FELFILI, J. M.; RESENDE, R. P. Conceitos e métodos em fitossociologia. Brasília: Universidade de Brasília. Comunicações Técnicas Florestais, v.5, n.1, p. 1-68, 2003.

FERRACIN, T. P.; SILVA, V. T.; MEDRI, P. S.; BIANCHINI, E.; PIMENTA, J. A.; TOREZAN, J. M. D. Comparação de parâmetros bióticos e abióticos entre fragmentos de floresta secundária nativa e um

FLORESTA, Curitiba, PR, v. 50, n. 1, p. 1071 - 1080, jan/mar 2020.

Fockink, G. D. et.al.

ISSN eletrônico 1982-4688

1079

DOI: $10.5380 /$ rf.v50 i1.61136 
reflorestamento de Pinus taeda L. Seminário: Ciências Biológicas e da Saúde, Londrina, v. 31, n.2, p. 179 $188,2010$.

GONÇALVES, A. R.; MARTINS, R. C. C.; MARTINS, I. S.; FELFILI, J. M. Bancos de sementes do subbosque de Pinus spp. e Eucalyrus spp. na Flona de Brasília. Revista Cerne, Lavras, v. 14, n. 1, p. 23 - $32,2008$.

INDUSTRIA BRASILEIRA DE ÁRVORES - IBÁ. Relatório 2017. São Paulo, 2017. 77 p. Disponível em:< http://iba.org/images/shared/Biblioteca/IBA_RelatorioAnual2017.pdf > Acesso em: 30 mar. 2018.

INSTITUTO BRASILEIRO DE GEOGRAFIA E ESTATÍSTICA - IBGE. Manual técnico da vegetação brasileira: sistema fitogeográfico, inventário das formações florestais e campestres, técnicas e manejo de coleções botânicas, procedimentos para mapeamentos. Rio de janeiro: IBGE- Diretoria de Geociências, 2012. 271 p. (Manuais Técnicos de Geociências, 1).

KEENAN, R.; LAMB, D.; WOLDRING, O.; IRVINE, T.; JENSEN, R. Resroration of plant biodiversity beneath tropical tree plantations in Northern Australia. Forestry Ecology and Management, v. 99, p. 117 - 131, 1997.

LOPES, I. S.; FELICIANO, A. L. P.; MARANGON, L. C.; ALENCAR, A. L. Dinâmica da regeneração natural no sub-bosque de Pinus caribaea Morelet. var. caribaea na Reserva Biológica de Saltinho, Tamandaré - PE. Ciência Florestal, Santa Maria, v. 26, n.1, p. 95 - 107, 2016.

MARTINS, S. V.; RODRIGUES, R. R.; GANDOLFI, S.; CALEGARI, L. Sucessão Ecológica: Fundamentos e aplicações na restauração de ecossistemas florestais. In: MARTINS, S. V. Ecologia de florestas tropicais do Brasil. 2.ed. Viçosa, MG: Ed. UFV, 2012. 368 p.

MODNA, D.; DURIGAN, G.; VITAL, M. V. C. Pinus elliottiii Engelm como facilitadora da regeneração natural da mata ciliar em região de Cerrado, Assis, SP, Brasil. Scientia Forestalis, Piracicaba, v. 38, n. 85, p. 73 - 83, 2010 .

OLIVEIRA, E. B.; OLIVEIRA, Y. M. M.; SCHAITZA, E. G. Plantações florestais comerciais e a biodiversidade. In: OLIVEIRA, Y. M. M.; OLIVEIRA, E. B. Plantações florestais: geração de benefícios com baixo impacto ambiental. Brasília, DF: Embrapa, 2017, 110 p.

POTTER, R. O.; CARVAlho, A. P.; Flores, C. A.; BOGNOlA, I. Solos do Estado de Santa Catarina. Rio de Janeiro: Embrapa Solos. Boletim de Pesquisa e Desenvolvimento, n. 46, 2004, 721 p.

RICHARDSON, D. M.; BOND, W. J. Determinantes of plants distribuition: evidence from pine invasions. The American Naturalist, v. 137, n. 5, p. 639 - 668, 1991.

SCHORN, L. A.; FELFILI, T. A. B.; KRÜGER, A.; PELlENS, G. C.; BUDAG, J. J; NADOLNY, M. C. Composição do banco de sementes no solo em áreas de preservação permanente sob diferentes tipos de cobertura. Revista Floresta, Curitiba, v. 43, n. 1, p. 49 - 58, 2013.

SENBETA, F.; TEKETAY, D.; NÄSLUND, B. A. Native woody species regeneration in exotic tree plantations at Munessa-Shashemene forest, southern Ethiopia. New Forests, v. 24, p. 131 - 145, 2002.

SHIMIZU, J.S. Pinus na silvicultura brasileira. Colombo: Embrapa Florestas, 2008. 223 p.

SERVIÇO FLORESTAL BRASILEIRO. Recursos florestais: as florestas plantadas. Sistema nacional de informações florestais. Brasília, 2018. Disponível em: <

http://www.florestal.gov.br/snif/recursos-florestais/as-florestas-plantadas> Acesso em: 04 maio 2018.

VASQUES, A. G.; NOGUEIRA, A. S.; KIRCHNER, F. F.; BERGER, R. Uma síntese da contribuição do gênero Pinus para o desenvolvimento sustentável no sul do Brasil. Revista Floresta, Curitiba, v. 37, n. 3, p. 445 - 450 , 2007.

VENZKE, T. S.; NERI, A. V.; CUNHA, J. F.; MARTINS, S. V. Regeneração natural do estrato arbóreoarbustivo sob talhão de Pinus caribaea var. hondurensis, Viçosa, MG, Brasil. Global Science. Technology, Rio Verde, v. 5, n. 3, p. 74 - 86, 2012.

VIANI, R. A. G.; DURIGAN, G.; MELO, A. C. G. A regeneração natural sob plantações florestais: desertos verdes ou redutos de biodiversidade? Ciência Florestal, Santa Maria, v. 20, n. 3, p. 533 - 552, 2010.

VOLTOLINI, J. C.; ZANCO, L. Densidade de plântulas e jovens de espécies de Floresta Atlântica em áreas com e sem o pinheiro americano (Pinus elliottii). Revista Biociências, Taubaté, v. 16, n. 2, p. 102 - 108, 2010. 